Artigo original

Hegemonia - Revista Eletrônica de Relações Internacionais do Centro Universitário Unieuro

ISSN: $1809-1261$

UNIEURO, Brasília, número 15, 2015, pp. 203-239.

Recebido em: 20/9/2014

Avaliado em:12/11/2014

Aprovado em: 18/2/2015

\title{
O Sistema Penitenciário Brasileiro e a Tortura
}

Alexandre Braga Cerqueira ${ }^{1}$

Resumo: O estudo e análise da evolução da humanidade do ponto de vista político e social aponta para um conjunto enorme de violências e atrocidades que foram cometidas em nome da estabilidade social; da justiça e da religião. Um dos métodos mais antigos utilizados para o cometimento de violências é a tortura. Após as duas grandes guerras mundiais, onde os regimes totalitários manifestos pelo fascismo na Itália e Espanha e o Nazismo alemão o mundo se viu obrigado a por um fim a práticas de violência contra a humanidade. Nessa lógica houve uma internacionalização dos Direitos Humanos para proteger os direitos humanos no nível internacional. Passados diversos anos é possível ver um cenário que sofisticação da tortura no sistema prisional, onde o Estado não oferece condições mínima de dignidade aos presos negando obrigações básicas como saúde e alimentação. O preso brasileiro termina sendo apenado duplamente. Uma por ficar com restrição de liberdade e a outra por ter que viver de forma degradante com violência sexual, uma alimentação de baixíssima qualidade, e uma assistência médica bastante precária, o que termina provocando mortes por tuberculose e AIDS

Palavras-Chave: Sistema Penitenciário; Tortura; Dignidade Humana.

Abstract: The study and the analysis of the evolution of humanity in the political and social point of view, points out to a huge number of violence and athrocities which were committed in the name of the social stability: of justice and religion. One of the oldest methods used to the violence's commited is the torture. After the two massives world of war, where by the totalirian regimes expressed by the facism in Italy, Spain and the

$1 \quad$ Mestre em Ciência Política. 
Artigo original

Hegemonia - Revista Eletrônica de Relações Internacionais do Centro Universitário Unieuro

ISSN: $1809-1261$

UNIEURO, Brasília, número 15, 2015, pp. 203-239.

German Nazism the entire world has had to remain to put the end on the violent practices against the humanity. Accordingly, there was a internationalization of human rights to protect it at an international level. Several years after it is possible to notice a scenery of sophisticated torture in prisions, where the State doesn't offer the minimum requirement of dignity to the prisoners, denying basic obligations like health and feeding. The Brazilian prisoner ends up been convicted twice. One for staying with restriction of liberty and another for living in a degraded way with sexual violence, a very low quality of feeding, and a very precarious health care. That causing TB deaths and AIDS.

Key words: Prison System; Torture; Human Dignity.

Introdução

Desde a antiguidade, a prática da tortura foi largamente utilizada, pois era instrumento para a obtenção de confissões inclusive era codificada, como no Código de Hamurabi, usado na Babilônia, que prescrevia penas terríveis aos condenados. (BORGES, 2004)

$\mathrm{Na}$ Grécia, os escravos estrangeiros eram permanentemente objetos de tortura e essa visão pode ser claramente percebida na obra de Flávia Camello que diz, "o escravo, não podia ser sensibilizado pelo sentimento moral e cívico, era torturado para dizer a verdade $[\ldots]^{\prime \prime}$ (TEIXEIRA, 2004)

No direito Romano, a prática da tortura era também comumente aplicada aos escravos, mas se estendia aos cidadãos comuns em crimes de traição contra o monarca, que era reconhecido como detentor de poderes divinos. (BORGES,2004)

Com o declínio do Império Romano e o fortalecimento da Igreja na Idade Média, onde havia forte ligação entre Igreja e Estado à tortura foi 
Artigo original

Hegemonia - Revista Eletrônica de Relações Internacionais do Centro Universitário Unieuro

ISSN: 1809-1261

UNIEURO, Brasília, número 15, 2015, pp. 203-239.

amplamente utilizada contra os infiéis e contra os insurgentes da ordem religiosa por meio dos tribunais da Inquisição. (PONTIERI, 2004)

Beccaria (2000) em sua obra "Dos delitos e das penas", afirmava já no século XVIII, que só o direito à força autorizaria um juiz a infringir uma pena a um cidadão quando ainda se duvida se ele é inocente ou culpado. E acrescentava:

"Eis uma proposição bem simples: ou o delito é certo ou é incerto. Se é certo, só deve ser punido com a pena fixada pela lei, e a tortura é inútil, pois já não se tem necessidade das confissões do acusado. Se o delito é incerto, não é hediondo atormentar um inocente? Com efeito, perante as leis, é inocente aquele cujo delito não se provou."

Aos poucos os Estados Europeus foram abolindo a tortura. Dentre os exemplos temos a Áustria em 1776, Prússia em 1756, Suécia em 1787, França em 1811, Portugal em 1821. (BORGES,2004)

1. A Origem da Tortura e as Convenções Internacionais

Antes mesmo da criação da ONU e dos demais tratados de direitos humanos, foi elaborada a Convenção de Genebra, na cidade de Genebra na Suíça em 22 de agosto de 1864. Essa convenção foi à instituidora do direito humanitário num âmbito internacional. A sua criação tinha por intencionalidade diminuir o sofrimento dos soldados e civis vítimas das guerras. Dessa lógica se estabeleceu que o direito de guerra e de paz passaria a ser dividido em ius ad bellum, que é o direito preventivo da guerra, e ius in bello, que é o direito ao estado de guerra. (COMPARATO, 2001)

O Brasil aderiu a Organização em 24 de outubro de 1945, no ano de sua criação (MELLO, 2003, p.63). Fábio Comparato ressalta que 
Artigo original

Hegemonia - Revista Eletrônica de Relações Internacionais do Centro Universitário Unieuro

ISSN: $1809-1261$

UNIEURO, Brasília, número 15, 2015, pp. 203-239.

atualmente enfatizam a tese de que o ius in bello já não poderia mais existir, pois se a guerra constitui um crime, não pode ser regulada. (COMPARATO, 2001)

Posteriormente a Convenção de Genebra foi revista. Seus princípios foram estendidos aos conflitos marítimos na Convenção de Haia, em 1907, e aos prisioneiros de guerra, na Convenção de Genebra de 1929. No âmbito internacional. A proteção geral dos Direitos Humanos ganhou força com a Declaração dos Direitos Humanos de 1948, com a elaboração de textos e tratados internacionais. Portanto pode-se afirmar que a positivação da tortura se deu com a formação da ONU - Organização das Nações Unidas, que teve como principal objetivo a cooperação de todos os Estados para com a proteção aos direitos humanos, direitos esses também resultantes dos impactos da Segunda Guerra. (TRINDADE, 2000)

Após a elaboração da Declaração Universal, chegou-se a um consenso de que todo indivíduo tem não só direitos fundamentais, mas também o direito a não ser torturado. Também por consenso, estatuiu-se que os Estados deveriam se empenhar para coibir a prática. Nesse sentido, ressalta-se a capacidade da ONU em responsabilizar os Estados quanto a atos de tortura, pois o fato de os governos terem adotado conjuntamente a Declaração Universal, significa dizer que as violações a quaisquer direitos humanos dizem respeito a todos eles. (PIOVESAN, 2002)

A Carta da ONU tinha como principal característica os princípios de direitos humanos, porém, não trazia seu conteúdo, fato que só aconteceria três anos depois com a Declaração Universal. Em seu artigo 68, criou a Comissão de Direitos Humanos, responsável pela criação da Declaração Universal dos Direitos do Homem, promulgada em 10 de 
Artigo original

Hegemonia - Revista Eletrônica de Relações Internacionais do Centro Universitário Unieuro

ISSN: $1809-1261$

UNIEURO, Brasília, número 15, 2015, pp. 203-239.

dezembro de 1948, através da Resolução n0217-A da Assembléia Geral das Nações Unidas. Foi ratificada pelo Brasil no mesmo dia.

A Declaração de 1948 introduz a concepção contemporânea de direitos humanos, marcada pela universalidade e indivisibilidade desses direitos, marcando decisivamente o Direito Internacional dos Direitos Humanos que é marcado pela criação da Declaração Universal, pois se os Estados reconheceram a universalidade dos direitos humanos, restou à Declaração Universal protegê-los. Ao final da Segunda Guerra Mundial, a tortura passou a ser repudiada por várias convenções e tratados ratificados pelo Brasil. (QUEIROZ, 2001)

Segundo Boucault "A Declaração de 1948 introduz a concepção contemporânea de direitos humanos, marcada pela universalidade e indivisibilidade desses direitos". Para ele, o Direito Internacional dos Direitos Humanos é marcado pela criação da Declaração Universal, pois se os Estados reconheceram a universalidade dos direitos humanos, restou à Declaração Universal protegê-los. (BOUCAULT, 1999)

Com a criação da OEA - Organização dos Estados Americanos, os estados americanos engajaram-se em proteger os direitos humanos a partir da defesa da democracia, que ia contra o modelo socialista adotado pelos países do Oeste após a Segunda Guerra, ou seja, no período conhecido como Guerra Fria. A eficácia na elaboração de atos e instrumentos internacionais de proteção aos direitos humanos num âmbito interamericano está condicionada à homogeneidade cultural de tais estados. (BOUCAULT, 1999)

A Assembleia Geral das Nações Unidas criou ainda o Pacto Internacional sobre Direitos Civis e Políticos e o Pacto Internacional sobre Direitos Econômicos, Sociais e Culturais, ambos em 1966. Quanto ao primeiro, vale ressaltar que Ihe foi atribuído um Comitê de Direitos 
Artigo original

Hegemonia - Revista Eletrônica de Relações Internacionais do Centro Universitário Unieuro

ISSN: $1809-1261$

UNIEURO, Brasília, número 15, 2015, pp. 203-239.

Humanos, com competência para receber e processar denúncias de direitos humanos, formuladas por qualquer cidadão dos Estados- Partes. (COMPARATO, 2001)

O Pacto Internacional sobre Direitos Civis e Políticos trouxe em seu artigo $2^{\circ}$ a obrigação de os Estados- Partes fazerem o necessário para adotar as medidas legislativas que permitam assegurar os direitos nele reconhecidos, caso a legislação própria ainda não os reconheça. No que tange à tortura, dispõe o artigo 70 que: "ninguém será submetido à tortura ou penas cruéis, desumanos ou degradantes". Os Estados membros se comprometem ainda a elaborar relatórios que devem ser encaminhados ao Secretário Geral da ONU. (QUEIROZ, 2001)

O Acordo foi construído pela Comissão de Direitos Humanos da Organização das Nações Unidas e aprovados em Assembléia Geral em 1966, e entrou em vigor em 1976, quando obteve a quantidade de ratificações necessárias, e foi ratificado pelo Brasil em 12 de dezembro de 1991, e promulgado pelo Decreto Legislativo n 592 , de 6 de dezembro de 1992. (PIOVESAN,2002)

A Declaração Universal dos Direitos do Homem explicita em seu artigo $3^{\circ}$ a proibição da tortura: "ninguém será submetido à tortura nem a tratamento ou castigo cruel, desumano ou degradante". No entanto, traz de forma mais ampla e ao mesmo tempo objetiva a previsão no art. 10 da Convenção contra a Tortura e outros Tratamentos ou Penas Cruéis, Desumanas ou Degradantes.

Art. 10: tortura designa qualquer ato pelo qual dores ou sofrimentos agudos físicos ou mentais infligidos intencionalmente a uma pessoa a fim de obter, dele ou de uma terceira pessoa, informações ou confissões; de castigá-la por ato que ela ou uma terceira pessoa tenha cometido, ou seja suspeita de ter qualquer outro motivo baseado em discriminação de qualquer natureza; quando tais dores ou sofrimentos são infligidos por um funcionário 
Artigo original

Hegemonia - Revista Eletrônica de Relações Internacionais do Centro Universitário Unieuro

ISSN: $1809-1261$

UNIEURO, Brasília, número 15, 2015, pp. 203-239.

publico ou outra pessoa no exercício de funções publicas, ou por sua instigação, ou com o seu consentimento ou aquiescência².

A citada convenção foi adotada pela Resolução 39/46 da Assembléia Geral das Nações Unidas em 10 de dezembro de 1984 e foi ratificada pelo Brasil em 28 de setembro de 1989.

Dentre os dispositivos da referida Convenção merece análise ainda o artigo 20, o qual determina que os Estados não poderão se abster de fatos relacionados à tortura. "Art. 20: Cada Estado tomará medidas eficazes de caráter legislativo, administrativo, judicial ou de outra natureza, a fim de impedir a prática de atos de tortura em qualquer território sob sua jurisdição"3.

A Convenção Interamericana para Prevenir e Punir a Tortura de 09 de dezembro de 1985, ratificada pelo Brasil em 20 de julho de 1989, foi uma Convenção elaborada pela OEA - Organização dos Estados Americanos que seguiu o molde da Convenção da ONU, porém com algumas diferenças no dispositivo que trata da tortura.

Art. 20: para os efeitos desta Convenção, entender-se-á por tortura todo ato pelo qual são infligidos intencionalmente a uma pessoa penas ou sofrimentos físicos ou mentais, com fins de investigação criminal, como meio de intimidação, como castigo pessoal, como medida preventiva, como pena ou qualquer outro fim. Entender-se-á também como tortura a aplicação, sobre uma pessoa, de métodos tendentes a anular a personalidade da vítima, ou a diminuir sua capacidade física ou mental, embora não causem dor física ou angústia psíquica. Não estarão compreendidas no conceito de tortura as penas ou sofrimentos físicos ou mentais que sejam unicamente conseqüência de medidas legais ou inerentes a elas, contanto que não incluam a realização dos atos ou a aplicação dos métodos a que se refere este artigo ${ }^{4}$.

2 Convenção contra a Tortura e outros Tratamentos ou Penas Cruéis, Desumanas ou Degradantes, art. $1^{\circ}$.

3 Convenção contra a Tortura e outros Tratamentos ou Penas Cruéis, Desumanas ou Degradantes, art. $2^{\circ}$.

$4 \quad$ Convenção Interamericana para Prevenir e Punir a Tortura de 09 de dezembro de 1985 , art. $2^{\circ}$. 
Artigo original

Hegemonia - Revista Eletrônica de Relações Internacionais do Centro Universitário Unieuro

ISSN: 1809-1261

UNIEURO, Brasília, número 15, 2015, pp. 203-239.

A Convenção Americana sobre Direitos Humanos, conhecida como Pacto de São José da Costa Rica foi promulgada em 22 de novembro de 1969 e ratificada pelo Brasil apenas em 25 de setembro de 1992. Foi um dos maiores instrumentos legal no sistema Interamericano. Nesta convenção ficaram reconhecidos e assegurados os direitos civis e políticos bem como um conjunto de mecanismos de proteção. Ao prever a proteção do ser humano quanto à tortura, em seu artigo 50, o Pacto de San José trouxe um dispositivo mais objetivo e sucinto.

Artigo $5^{\circ}$ - Direito à integridade pessoal

1. Toda pessoa tem direito a que se respeite sua integridade física, psíquica e moral.

2. Ninguém deve ser submetido a torturas, nem a penas ou tratamentos cruéis, desumanos ou degradantes. Toda pessoa privada de liberdade deve ser tratada com o respeito devido à dignidade inerente ao ser humano ${ }^{5}$.

2. A Tortura no Ordenamento Jurídico Brasileiro - Aspectos Positivos e Negativos e sua repercussão para o Conjunto da Sociedade

Fazendo um recorte na história do nosso país constatamos que a prática da tortura no Brasil teve início já nos primeiros anos do descobrimento contra os índios e posteriormente contra os negros, perpassando a colônia, o império e na república (PONTIERI,2004).

A primeira Constituição do Brasil foi a de 1824, chamada também de Constituição Imperial, quando o Brasil deixou de ser Colônia. Tal Constituição foi a que vigorou até 1889 , sendo a mais longa da história do país. Essa Constituição já coibia a prática de tortura. (HERKENHOFF, 2011) 
Artigo original

Hegemonia - Revista Eletrônica de Relações Internacionais do Centro Universitário Unieuro

ISSN: $1809-1261$

UNIEURO, Brasília, número 15, 2015, pp. 203-239.

Anteriormente ao Brasil Império, estavam em vigor as Ordenações Filipinas. O Código Penal do Império foi o primeiro Código Penal do Brasil e entrou em vigor no dia 08 de janeiro de 1831 vigendo até 1891 , quando - Brasil deixou de ser império e passou a ser república. Passou a ser chamado então de Código Penal dos Estados Unidos do Brasil, a partir dos Decretos no 847 e 1.127, ambos de 1890. (KOEMER JÚNIOR, 2011)

O processo de colonização português tinha uma lógica de dominação que incluía as práticas de tortura. Índios e escravos foram vítimas de violência e meios cruéis como castigo. Embora a Constituição Brasileira de 1824, proibisse a tortura, açoites, marcas de ferro quente e demais penas cruéis, os escravos eram duramente castigados por serem vistos como sub-humanos, portanto desprovidos de direitos. A Constituição do Império, em seu artigo 179, coibia a prática da tortura a partir dos procedimentos penais: "XIX- Desde já ficam abolidos os açoites, a tortura, a marca de ferro quente e todas as penas cruéis." (TEIXEIRA, 2004)

Apesar da constituição de 1824 ter proibido a tortura, já com princípios de direitos humanos, os negros e os escravos não tinham seus direitos assegurados. Eram vítimas de violência pelos Senhores, que ficavam impunes. O que acontecia era o inverso, havia sim uma previsão legal para castigos. (BIAZEVIC, 2011)

O Código Criminal do Império que data de 1830, portanto, posterior à Constituição, obrigaria os negros e escravos a cumprir a pena imposta pelo juiz. 0 artigo 60 do Código Criminal do Império ainda fixava o número de açoites aplicado somente aos escravos.

Art. 60: Se for o réu escravo, e incorrer em pena que não seja a capital ou de Galés, será condenado na de açoites, e, depois de sofrer, será entregue a seu senhor, que se obrigará a trazê-lo com um ferro pelo tempo e maneira que 
Artigo original

Hegemonia - Revista Eletrônica de Relações Internacionais do Centro Universitário Unieuro

ISSN: 1809-1261

UNIEURO, Brasília, número 15, 2015, pp. 203-239.

- juiz designar. O numero de açoites será fixado na sentença, e o escravo não poderá levar por dia mais de cinqüenta. (PIERANGELI, 2001)

Paulo Evaristo ressalta que desde o período monárquico a população já se rebelava contra a opressão política. Dentre alguns exemplos têm-se a Sabinada (guerra na Bahia ocorrida de 1831 a 1837); Guerra dos Farrapos (Rio Grande do Sul em 1835) e a Balaiada (Maranhão de 1838 a 1841). Para reprimir tais guerras foi criada, em 1831, a Guarda Nacional. A Guarda Nacional era uma força auxiliar ao Exército, a ela competia à repressão a opositores internos. (ARNS, 1985)

Como tinha uma ligação com proprietários rurais, a Guarda Nacional foi se enfraquecendo a partir da ascensão da burguesia e da Guerra do Paraguai (1864-1870). Com isso o exército passou a intervir abertamente nas questões políticas, fazendo com que a Guarda Nacional fosse extinta. (ARNS, 1985)

\subsection{Tortura na República}

O primeiro código jurídico da República, o de 1890, aboliu a pena de morte e as penas infamantes. O Código previa, em seu art. 41, parágrafo $2^{\circ}$, a incidência de uma circunstância agravante, para todos os crimes, quando a dor física resultante dos mesmos fosse aumentada por atos de crueldade.

O Código de 1940, em sua Parte Geral anterior à Reforma de 1984, previa a tortura em circunstâncias agravantes, nos seguintes termos:

Art. 44. São circunstâncias que sempre agravam a pena, quando não constituem ou qualificam o crime:

II - ter o agente cometido o crime com o emprego de veneno, fogo, explosivo, asfixia, tortura ou outro meio insidioso ou cruel ou de que podia resultar perigo comum. 
Artigo original

Hegemonia - Revista Eletrônica de Relações Internacionais do Centro Universitário Unieuro

ISSN: $1809-1261$

UNIEURO, Brasília, número 15, 2015, pp. 203-239.

Com o golpe de Getúlio Vargas em 1937, foi instalada uma ditadura que durou 10 anos e sua motivação foi à contenção do Plano Cohen que segundo os getulistas eram um movimento liderado pela Ação Integralista Brasileira para impor uma revolução comunista no Brasil. Esse golpe foi denominado de Estado Novo e desde sua implantação em 1937 tinha características de uma ditadura militar.

O fechamento do Congresso Nacional e a extinção dos partidos políticos; a autonomia total do poder executivo, podendo o presidente legislar por Decreto - Lei; desarmamento dos policiais estaduais que passaram a ser comandados pelas Forças Armadas, e; censura dos meios de comunicação e a criação do DIP (Departamento de Imprensa e Propaganda) que exercia esse controle nacional da censura, foram às principais características da Constituição de 1937 apresentada pelo novo regime que serviria de parâmetro anos mais tarde. (COIMBRA, 2002)

Segundo Teixeira, a tortura praticada durante o Estado Novo foi uma herança cultural do Brasil Império. Sua prática, já no Brasil Republicano, foi marcante e diferenciada, já que houve um fortalecimento dos Departamentos Policiais. A partir desse fortalecimento, os referidos departamentos se destinaram a conter a repressão política, ou seja, prender e punir os opositores do governo. (TEIXEIRA, 2004)

A tortura teve seu auge no Brasil na época do Regime Militar, que data de 1964 até 1979, sendo que o governo militar se deu até o ano de 1985. Naquela época, a tortura propagou-se através de três centros, para onde eram levados os presos políticos: no Exército, o DOI-CODI (Departamento de Operações e Informações- Centro de Operações de Defesa Interna); na Aeronáutica o CISA (Centro de Informações e Segurança da Aeronáutica); e na Marinha o CENIMAR (Centro de Informações da Marinha). 
Artigo original

Hegemonia - Revista Eletrônica de Relações Internacionais do Centro Universitário Unieuro

ISSN: $1809-1261$

UNIEURO, Brasília, número 15, 2015, pp. 203-239.

Com isso, a tortura passou a fazer parte dos currículos dos militares, os quais tinham aulas práticas e a utilizavam em prisioneiros que praticavam crimes políticos, ou seja, manifestações que iam contra o Governo Militar e a Segurança Nacional. (ARNS, 1985)

No episódio da Favela Naval em Diadema, São Paulo, ocorrido em março de 1997. Policiais militares, no exercício de suas atribuições, quais sejam: garantir a ordem pública e a proteção do cidadão efetuaram uma blitz em uma rua deserta da favela. Um cinegrafista amador registrou por três dias a atuação dos policiais. (FERREIRA, 2011)

Suas atividades se resumiram em abordar cidadãos e, logo após, desferir tapas, socos e outros tipos de agressões, além de lhes extorquir dinheiro. Tudo sem que houvesse qualquer motivo e meios de defesa para esses cidadãos. $O$ excesso dos policiais foi tanto que ainda resultou na morte de um morador que foi atingido pelo disparo de arma de fogo de um dos policiais. (FERREIRA, 2011)

O caso da Favela Naval foi marcante não apenas por ter motivado a edição da Lei de Tortura, mas também para que autoridades se conscientizassem à respeito das formas de atuação das policias, dentre elas a tortura, para que alguma providência fosse tomada. Esse caso foi o marco fundamental para a rápida votação de um projeto já existente no Senado Federal, resultando na edição da Lei 9.455, de 07 de abril de 1997, a Lei de Tortura. (TEIXEIRA, 2004)

De acordo com Camargo Aranha com respeito à culpabilidade a jurisprudência constitui uma curiosa interpretação: o dolo é presumido, e emerge em conformidade com a materialidade e a autoria, enquanto a culpa necessita ser demonstrada pela acusação. Admite-se o dolo presumido porque é incluído entre as chamadas circunstâncias 
Artigo original

Hegemonia - Revista Eletrônica de Relações Internacionais do Centro Universitário Unieuro

ISSN: $1809-1261$

UNIEURO, Brasília, número 15, 2015, pp. 203-239.

concomitante, portanto existentes desde que provado o fato específico. (ARANHA, 1994)

\subsection{Os Crimes Hediondos e a Lei da Tortura}

Em virtude do artigo 50, inciso XLIII foi elaborada a Lei n. 8.072/90 que trata dos crimes hediondos. Essa lei surgiu em razão da manifestação da sociedade pela violência de crimes como seqüestros (TEIXEIRA, 2004). Nessa lei o crime de tortura não foi tipificado, mas assemelhado aos crimes hediondos. O legislador, não só vedou a possibilidade de concessão do benefício da graça ou anistia, como estendeu ao indulto, fiança e a liberdade provisória.

Outra questão contida na Lei n. 8.072/90 foi à proibição do regime de progressão no cumprimento da pena para o delito de tortura, e que na Lei n. 9.455/97 em seu artigo $1^{\circ}, \S 77^{\circ}$ estabelece que "o condenado por crime previsto nesta lei, salvo hipótese do $\S 2^{\circ}$, iniciará o cumprimento da pena em regime fechado".

Esse artigo foi um dos mais controvertidos da Lei n. 8.072/90 face ao delito de tortura, com amplas discussões e interpretações, inclusive com a defesa da ampliação da possibilidade de cumprimento de pena "inicialmente fechado" trazida pela lei de tortura e vedada pela lei dos crimes hediondos deveria ser a estes também estendidos.

A tortura que fora assemelhada aos crimes hediondos por força da Lei n. 8072/90, ganhava um leque de restrições maior e ainda não tinha sua conduta definida. A tortura apesar de defesa na Constituição e na legislação infraconstitucional não era sequer definida, ou seja, ainda não havia norma especifica capaz de fomentar a sua aplicação.

A responsabilização dos acusados pelo crime de tortura está diretamente relacionada à prova penal. Nas hipóteses em que a tortura deixa vestígios, não se poderá dispensar a realização do exame de corpo 
Artigo original

Hegemonia - Revista Eletrônica de Relações Internacionais do Centro Universitário Unieuro

ISSN: $1809-1261$

UNIEURO, Brasília, número 15, 2015, pp. 203-239.

de delito para a formação do conjunto probatório, porém isso não significa o retorno absoluto ao sistema da prova legal ou tarifada, como poderia ser pensado frente à regra disposta no art. 158 do Código de Processo Penal. (LIMA, 2006)

Portanto, o tema da prova no crime de tortura, não bastará o exame de corpo de delito para evidenciar o nexo de casualidade entre os vestígios do crime e a prova da autoria. Sem receio, preconceito ou rigor formal, deve o julgado, sempre que necessário, exigir um esforço intelectivo para a afirmação da autoria. (LIMA, 2006)

\section{Análise da Lei 9.455/97 e o Enfrentamento Institucional da Tortura}

O crime de tortura foi historicamente marcado pela polêmica. Uma das razões é por se tratar de afronta à liberdade, à democracia e com a previsão constitucional ela precisava de um balizamento legal adequado. Um dos institutos que previu de forma legal o delito da tortura foi o Estatuto da Criança e do Adolescente - Lei n. 8.069, de 15 de julho, de 1990 , que trazia a seguinte previsão em seu artigo 233, in verbis:

Submeter criança ou adolescente sob sua autoridade, guarda ou vigilância a tortura: pena - reclusão de um a cinco anos. $\S 1^{\circ}$ se resultar lesão corporal grave: pena - reclusão de dois a oito anos;

$\S 2^{\circ}$ se resultar lesão corporal gravíssima: pena - reclusão de quatro a doze anos;

$\S 3^{\circ}$ se resultar morte: pena - reclusão de quinze a trinta anos.

Percebemos que, muito timidamente, agora, existia a previsão legal de um delito de tortura tipificado e penalizado pelo legislador que tentou individualizar a espécie do delito, tentando proteger a criança e o adolescente contra a violência de quem os tinha sob sua autoridade, guarda ou vigilância. 
Artigo original

Hegemonia - Revista Eletrônica de Relações Internacionais do Centro Universitário Unieuro

ISSN: $1809-1261$

UNIEURO, Brasília, número 15, 2015, pp. 203-239.

Essa tipificação da tortura contra criança ou adolescente, trouxe a baila novas discussões e a respeito da tipificação do delito de tortura em nossa legislação, inclusive com controvérsias entre os doutrinadores.

A Lei n. 9.455/97, atual Lei de Tortura, supriu a lacuna existente e tratou dos ilícitos penais envolvendo essa prática. Em seu artigo $4^{\circ}$ ela revogou expressamente o artigo 233 do Estatuto da Criança e do Adolescente, trazendo um aumento legal no caso de tortura cometida contra menor que pode variar de um sexto a um terço de acordo com seu artigo $1^{\circ}, \S 4^{\circ}$, II, in verbis:

Art. $1^{\circ}$. Aumenta-se a pena de um sexto até um terço:

I - Omissis;

II - Se o crime é cometido contra criança, gestante, deficiente e adolescente;

III - Omissis.

Também anterior à edição da lei, o delito de tortura está previsto no Código Penal Brasileiro em dois dispositivos. Primeira como mera circunstância agravante da pena, conforme dispõe o art. 61, inciso II, alínea $d$ :

Art. 61- São circunstâncias que sempre agravam a pena, quando não constituem ou qualificam o crime:

II- ter o agente cometido o crime;

d) com emprego de veneno, fogo, explosivo, tortura ou outro meio insidioso ou cruel, ou de que podia resultar perigo comum $[\ldots]^{6}$.

Ainda quanto à previsão no Código Penal, a tortura também se encontra como qualificadora no caso de homicídio, conforme o dispositivo:

Art. 121- Matar alguém:

Parágrafo $2^{0}$ - Se o homicídio é cometido:

III- com emprego de veneno, fogo, explosivo, asfixia, tortura ou outro meio insidioso ou cruel, ou de que possa resultar perigo comum $[\ldots]^{7}$. 
Artigo original

Hegemonia - Revista Eletrônica de Relações Internacionais do Centro Universitário Unieuro

ISSN: 1809-1261

UNIEURO, Brasília, número 15, 2015, pp. 203-239.

Atenta-se que, quanto aos referidos dispositivos, se diferem os mesmos do crime de tortura qualificada, contida no parágrafo $3^{\circ}$ do art. 10 da Lei de Tortura: "se resulta lesão corporal de natureza grave ou gravíssima, a pena é de reclusão de 4 (quatro) a 10 (dez) anos; se resultar morte, a reclusão é de 8 (oito) a 16 (dezesseis) anos"8.

Tal diferença, segundo Mário Coimbra se dá pelo fato de ser a tortura qualificada, um crime qualificado pelo resultado. Dessa forma se o agente agiu com dolo, ou seja, vontade de torturar, e o resultado com morte ele cometeu o delito de tortura qualificada. (COIMBRA, 2002)

No mesmo sentido, vale citar o entendimento de Guilherme de Souza Nucci acerca da tortura qualificada: "... o crime qualificado pelo resultado pode dar-se com o dolo na conduta antecedente (tortura) e dolo ou culpa na conseqüente (lesão morte)." (NUCCI, 2006)

A mesma regra aplica-se também no caso de qualificadora por lesões corporais, porém com uma ressalva. As lesões apenas serão qualificadoras do crime de tortura, se forem de natureza grave ou gravíssima, conforme o parágrafo $3^{\circ}$. (COIMBRA,2002)

Posteriormente a estas considerações e distinções do crime de tortura com os dispositivos do Código Penal que prevêem a mesma, a lei traz uma definição do crime: "Art.10-Constitui crime de tortura: Iconstranger alguém com emprego de violência ou grave ameaça, causando-Ihe sofrimento físico ou mental;" ${ }^{\prime \prime}$. No art. $1^{0}$ inciso II da Lei $n^{\circ}$ 9.455/97 in verbis:

submeter alguém, sob sua guarda, poder ou autoridade, com o emprego de violência ou grave ameaça, a intenso sofrimento físico ou mental, como forma de aplicar castigo pessoal ou medida de caráter preventivo.

$8 \quad$ Lei $9.455 / 97$, art. $1^{\circ}$, parágrafo 30

$9 \quad$ Lei $9.455 / 97$, art. 10 , I. 
Artigo original

Hegemonia - Revista Eletrônica de Relações Internacionais do Centro Universitário Unieuro

ISSN: $1809-1261$

UNIEURO, Brasília, número 15, 2015, pp. 203-239.

Submeter vem do latim submittere significa sujeitar, subjugar, pressupondo vigilância. Poder significa a faculdade de deliberar, agir, mandar, exercer domínio e força. Autoridade é o poder de se fazer obedecer, de dar ordens, tomar decisões. (LIMA,1997)

Portanto, o crime de tortura é caracterizado pela sujeição de alguém que está sob o cuidado, o domínio ou obrigado a obediência do sujeito ativo, com o uso de violência ou grave ameaça, a intenso sofrimento físico ou mental, visando a aplicação de castigo pessoal ou medida de caráter preventivo. É muito comum a modalidade criminosa no cotidiano das delegacias de polícia, principalmente aos autores de crimes contra o patrimônio, contra os costumes e tráfico ilícito de substâncias entorpecentes. (LIMA, 1997)

No caso da tortura o bem jurídico tutelado é a dignidade humana e a integridade física ou psíquica da vitima, violadas pela pratica delituosa. Para José Ribeiro Borges a lei brasileira estendeu o conceito de tortura se comparada com outros tratados internacionais, na medida em que dispõe que a tortura somente pode ser praticada por agentes públicos, ou seja, caracteriza-se crime próprio. A lei brasileira considera sujeito ativo do delito qualquer pessoa, além de contemplar outras modalidades de conduta. (BORGES, 2004)

A autora Flávia Camello Teixeira também explica a amplitude do sujeito ativo nos crimes de tortura, podendo ser qualquer pessoa. Porém, critica tal dispositivo, entendendo que o tratado internacional ao definir tortura como crime próprio está de alguma forma protegendo o cidadão contra abusos desses agentes, e que a lei brasileira, ao estender o conceito, acaba por não protegê-lo. (TEIXEIRA, 2004)

A Lei de Tortura traz seis tipos de modalidade do crime: 0 artigo 10, inciso I e suas alíneas da referida lei, prevê três tipos de crimes. O 
Artigo original

Hegemonia - Revista Eletrônica de Relações Internacionais do Centro Universitário Unieuro

ISSN: $1809-1261$

UNIEURO, Brasília, número 15, 2015, pp. 203-239.

primeiro é chamado de tortura-prova ou tortura-persecutória, pois tem como fim a obtenção de informação, declaração ou confissão da vítima ou terceiro. O segundo é chamado de tortura-crime tem como fim provocar ação ou omissão de natureza criminosa. O terceiro é chamado de torturaracismo, já que é realizada em razão de discriminação racial ou religiosa. (CAPEZ,2006)

Ressalta Fernando Capez (2006, p.661) que, o elemento subjetivo nessas três modalidades de crime de tortura é o dolo com finalidade especial, ou seja, exige-se a vontade do autor em empregar a violência ou grave ameaça. Ainda sobre o emprego de violência ou grave ameaça, vale ressaltar que, se forem empregados tais meios, mas a ação tiver sido interrompida por circunstâncias alheias à vontade do agente, o crime restará tentado. (CAPEZ, 2006)

Outra modalidade de tortura contida na lei, é a do art. 10, inciso II. É a chamada tortura-castigo, pois parte da compreensão da aplicação da tortura como castigo pessoal ou de caráter preventivo. Tal modalidade, esta sim, é classificada como crime próprio. Como explica José Ribeiro Borges (2004):

(...) Exigindo-se que o sujeito ativo se revista de uma qualidade ou condição pessoal, estabelecendo-se entre autor e vítima uma relação de subordinação ou de dependência, mas não, necessariamente, a qualidade de funcionário público do agente (...).

Dessa forma, não precisa ser o autor necessariamente funcionário público, mas qualquer um que detenha a guarda da vítima. Um exemplo "é o espancamento de crianças pequenas, realizado por pais ou outros responsáveis por sua guarda." (NUCCI,2006)

Quanto à quinta modalidade, prevista no art. $1^{\circ}$, parágrafo $1^{0}$, exige-se que o sujeito passivo esteja preso ou sujeito à medida de 
Artigo original

Hegemonia - Revista Eletrônica de Relações Internacionais do Centro Universitário Unieuro

ISSN: 1809-1261

UNIEURO, Brasília, número 15, 2015, pp. 203-239.

segurança. Porém, é importante destacar que, apesar de o sujeito ativo poder ser qualquer pessoa, somente o Estado pode prender alguém. Dessa forma, subentende-se que aquele deve ser agente público. (NUCCI, 2006)

Esse tipo de tortura ocorre quando o ato praticado, previsto ou não em lei, não gere à vítima sofrimento físico ou mental. (CAPEZ, 2006)

A sexta e última modalidade contida no art. $1^{\circ}$, parágrafo $2^{\circ}$ da Lei de Tortura, faz referência àquele que se omite em face de condutas de tortura, quando tinha o dever de evitá-las ou apurá-las. Dessa forma, pratica o citado crime o agente que é conivente com a tortura, podendo essa conivência ser durante a prática, ou posterior, quando, sabendo, nada faz para apurar 0 delito. O parágrafo $4^{\circ}$ traz as hipóteses de aumento de pena.

Art. 40- Aumenta-se a pena de $1 / 6$ (um sexto) até $1 / 3$ (um terço): I- se o crime é cometido por agente público;

II- se o crime é cometido contra criança, gestante, portador de deficiência, adolescente ou maior de 60 (sessenta) anos;

III- se o crime é cometido mediante seqüestro ${ }^{10}$.

O parágrafo $6^{\circ}$ da Lei de Tortura considera ainda que os crimes nela previstos são inafiançáveis e não são passiveis de graça ou anistia. Decorre esse dispositivo do texto constitucional, art. 50, XLIII, que ainda dispõe que a tortura não é um crime hediondo, mas sim um delito equiparado a este. Para o artigo $5^{\circ}$ inciso XLIII do texto constitucional os crimes inafiançáveis e insuscetíveis de graça ou anistia são:

a prática da tortura, o tráfico ilícito de entorpecentes e drogas afins, o terrorismo e os definidos como crimes hediondos, por eles, respondendo os mandantes, os executores e os que, podendo evitá-los, se omitirem; ${ }^{11}$.

10 Lei $9.455 / 97$, art. 40.

11 Constituição Federal de 1988, art. 50, XLIII 
Artigo original

Hegemonia - Revista Eletrônica de Relações Internacionais do Centro Universitário Unieuro

ISSN: $1809-1261$

UNIEURO, Brasília, número 15, 2015, pp. 203-239.

Por graça entende-se o indulto individual, ou seja, o perdão concedido pelo Presidente da República por meio de decreto. Para Nucci (2006, p.744) o indulto também deve ser entendido como cabível, já que é o perdão coletivo. Já para Capez (2006, p.677), a concessão do beneficio do indulto é vedada para a tortura, já que não é previsto desde o dispositivo constitucional, apesar do autor também definir indulto como graça coletiva.

Ainda sobre o mesmo dispositivo da Lei de Tortura, vale lembrar que a mesma permite ao autor de tal delito a concessão de liberdade provisória, ao contrário da Lei 8.072/90 - Lei dos Crimes Hediondos. De acordo com Mário Coimbra (2002, p.197):

\begin{abstract}
É bem verdade que a Lei 8.072/90 vedou, expressamente, a concessão da liberdade provisória aos autores dos crimes em análise. No entanto a Lei 9.455/97, ao regular, especificamente, a tortura, repetiu 0 texto constitucional, permitindo, por conseguinte, que o autor de crime de tortura possa receber a liberdade provisória, apesar de se tratar de delito inafiançável. A nova lei, pelo critério da especialidade, deve prevalecer, portanto, em relação aos ditames da Lei 8.072/90.
\end{abstract}

No entendimento de Fernando Capez (2006, p.677) também é cabível a liberdade provisória. Para tanto, o autor explica ainda que o fato de o legislador não prever na Lei de Tortura a proibição da liberdade provisória, fez com que surgisse daí duas posições. A primeira significaria uma aplicação subjacente à posição da Lei dos Crimes Hediondos, o qual proíbe tal concessão. A segunda seria a permissão da concessão, pois se o legislador pretendesse proibi-la, teria feito expressamente na lei.

O artigo $2^{\circ}$ da Lei de Tortura dispõe que tal lei será aplicada quando o delito for cometido fora do território nacional. Tal fato decorre do princípio da extraterritorialidade. Essa regra emana do direito internacional. A partir desse dispositivo, têm-se duas hipóteses de aplicação da lei ao cidadão que comete o crime em outro Estado: quando 
Artigo original

Hegemonia - Revista Eletrônica de Relações Internacionais do Centro Universitário Unieuro

ISSN: 1809-1261

UNIEURO, Brasília, número 15, 2015, pp. 203-239.

a vítima for brasileira ou quando o agente encontrar-se em território brasileiro. (CAPEZ, 2006)

A última questão relevante no tocante à Lei de Tortura diz respeito à progressão de regime. A Lei de Tortura permitiu tal progressão ao estabelecer em seu art. $1^{0}$ parágrafo 70 que 0 regime inicial será 0 fechado. Ademais, não há mais o que se discutir quanto à possibilidade ou não de progressão de regime, tanto nos crimes hediondos, quanto nos crimes de tortura, já que a Lei 11.464/07 declarou a inconstitucionalidade do parágrafo $1^{0}$ do artigo $2^{\circ}$ da Lei 8.072/90 - Lei dos Crimes Hediondos, o qual vedava tal progressão. (CAPEZ, 2007)

4. Análise da Eficácia, Eficiência, Equidade e Repercussão da Legislação no Enfrentamento da Tortura no Sistema Penitenciário

A tortura tem sido objeto de acordos, tratados e convenções internacionais objetivando o seu combate e erradicação. Os instrumentos internacionais são visto como uma prática hedionda e utilizada para conter a liberdade de expressão, do pensamento e dos direitos do cidadão. (SILVA; LAVORENTI, 2004)

No contexto internacional a tortura é tratada como crime próprio, ou seja, com característica particular do sujeito ativo. A Lei de tortura inovou no que diz respeito ao que já havia sido assinado e ratificado pelo Brasil, quando passou a tipificar a conduta em seu ordenamento jurídico, o definiu como crime comum, praticado por qualquer pessoa. (SILVA, 1999)

A conduta de tortura com o advento da Declaração sobre a proteção de todas as pessoas contra tortura e outras penas ou 
Artigo original

Hegemonia - Revista Eletrônica de Relações Internacionais do Centro Universitário Unieuro

ISSN: 1809-1261

UNIEURO, Brasília, número 15, 2015, pp. 203-239.

tratamentos cruéis desumanos ou degradantes de 1975, que a definiu em seu artigo $1^{\circ}$ da seguinte maneira:

"Para os efeitos da presente Declaração, entende-se por tortura todo o ato pelo qual um funcionário público, ou outrem por ele instigado, inflija intencionalmente a uma pessoa penas ou sofrimentos graves, físicos ou mentais, com o fim de...".

A Convenção contra tortura e outros tratamentos ou penas cruéis, desumanos ou degradantes de 1984 , trouxe em seu artigo $1^{\circ}$ a seguinte definição:

"[...] quando tais dores ou sofrimentos são infligidos por um funcionário público ou outra pessoa no exercício de funções públicas, ou por sua instigação ou com o seu consentimento ou aquiescência $[\ldots] "$ ".

Na Convenção Interamericana Para Prevenir e Punir a Tortura de 1985 o crime de tortura foi definido como uma qualidade ou condição necessária ao sujeito ativo que a praticasse, ou seja, seguiu a lógica dos tratados dando ao delito a classificação de crime próprio, conforme o artigo $3^{\circ}$ :

Serão responsáveis pelo delito de tortura:

a) Os empregados ou funcionários públicos que, atuando nesse caráter, ordenem sua execução ou instiguem ou induzam a ela, cometam-no diretamente ou, podendo impedi-lo, não o façam.

b) As pessoas que, por instigação dos funcionários ou empregados públicos a que se refere a alínea $a$, ordenem sua execução, instiguem ou induzam a ela, cometam-no diretamente ou nele sejam cúmplices.

Portanto, em todos os compromissos internacionais que o Brasil assumiu a tortura foi entendida como crime próprio. Era necessária uma condição específica, inerente ao indivíduo que a praticava para a caracterização do delito, onde o sujeito ativo do delito de tortura tinha que ser funcionário público, empregado público ou estar no exercício de uma 
Artigo original

Hegemonia - Revista Eletrônica de Relações Internacionais do Centro Universitário Unieuro

ISSN: $1809-1261$

UNIEURO, Brasília, número 15, 2015, pp. 203-239.

função pública, por estes instigados, induzidos, com seu conhecimento, aquiescência ou cumplicidade. (BORGES, 2004)

A Lei n. 9.455/97, conhecida como a Lei de tortura, apresentou uma grande diferença em relação a todos os compromissos relacionados ao tema e assumidos pelo Brasil no cenário internacional, com uma definição diversa, ao delito a classificação de crime comum, o alterou significativamente o contorno da aplicação da Lei. Na compreensão da Lei 9.455/97 a tortura pode ser praticada por qualquer pessoa, não mais apenas por um tipo de sujeito com certas características ou condições pessoais.

Para Alberto Silva Franco (1997, p.60) a classificação da tortura de crime comum pela Lei n. 9.455/97, como "o mais grave defeito deste diploma legal". Para o autor, O Brasil como signatário de todos os tratados e acordos internacionais de proteção dos direitos humanos os quais definiram a tortura como crime próprio, o Brasil, por força dos artigos $5^{\circ}, \S 1^{\circ}$ e $\S 2^{\circ}$ da Constituição de 1988 , já havia inserido em seu ordenamento interno a figura típica de tortura.

Para Nilton João de Macedo Machado, apesar de simples e com poucos artigos, a Lei n. 9.455/97 é muito abrangente e apresenta diversos defeitos exigindo dos juristas, grande esforço de interpretação e entende que o crime de tortura não poderia ter sido classificado como crime comum. (MACHADO, 2001, p.19)

O artigo $5^{\circ}, \S 1^{\circ}$ da Constituição Federal de 1988 afirma que:

"As normas definidoras dos direitos e garantias fundamentais têm aplicação imediata".

O parágrafo $2^{\circ}$ do mesmo artigo da Constituição diz que:

"Os direitos e garantias expressos nessa Constituição não excluem outros decorrentes do regime e dos princípios por 
Artigo original

Hegemonia - Revista Eletrônica de Relações Internacionais do Centro Universitário Unieuro

ISSN: $1809-1261$

UNIEURO, Brasília, número 15, 2015, pp. 203-239.

ela adotados, ou dos tratados internacionais em que a República Federativa do Brasil seja parte".

Alberto Silva Franco entende que os mandamentos constitucionais citados acima deixam claros que os acordos que definiram a tortura, por serem pactos que tratam dos direitos humanos, são detentores de força Constitucional de aplicação e exigência imediata, pois já haviam sido incorporados automaticamente à legislação consoante os artigos $5^{\circ}, \S 1^{\circ}$ e $\S 2^{\circ}$ da Constituição Federal. (FRANCO, 1997,p.59)

Portanto, a classificação de crime próprio, não poderia ter sido mudada pela Lei n. 9.455/97, que alterou o disposto nestes instrumentos internacionais dando ao delito classificação contrária de crime comum.

Sérgio Salomão Shecaira (1997, p.2) posiciona-se no mesmo sentido afirmando que:

Melhor seria, ainda, a delimitação do objeto e alcance da lei, que o crime de tortura viesse classificado como crime próprio - aquele que pode ser cometido por determinada categoria de pessoas - e não como crime comum, cujo autor pode vir a ser qualquer pessoa.

Para Rui Stoco a conduta de tortura apenas deveria se constituir como crime próprio e que outros casos em que ocorresse tal comportamento ilegal por parte dos particulares, estes deveriam ser punidos por meio de uma das várias figuras típicas existentes já existentes no Código Penal. (STOCCO, 1997, p.4)

Os partidários que defendem a idéia da classificação de crime comum ao delito de tortura projetam suas assertivas no sentido de que tal classificação seria necessária. Para Alezandro Del Toro Marzal (1997, p.60) que afirma que:

A tortura deveria ser castigada em si mesma e por si mesma, em razão de seus detestáveis métodos e por seus fins contrários à liberdade e dignidade. Destarte, não considerar que particulares ou extremistas de qualquer 
Artigo original

Hegemonia - Revista Eletrônica de Relações Internacionais do Centro Universitário Unieuro

ISSN: $1809-1261$

UNIEURO, Brasília, número 15, 2015, pp. 203-239.

tendência possam também empregar a tortura, tanto em relação a outros indivíduos, como aos próprios funcionários públicos, é limitação demagógica e contraproducente...

Portanto, deve sim considerar os particulares, pois qualquer pessoa pode praticar o crime de tortura, pois não faz sentido definir que o crime de tortura é "monopólio do tipo pelos funcionários públicos" não ajudaria em nada na perspectiva dos direitos humanos. Como bem assevera Alberto Silva Franco "será preferível, em matéria de tortura, uma figura típica que possa ser melhorada, do que a carência tipológica." (FRANCO, 1997)

Esse mesmo entendimento que é compartilhado por parte da doutrina, entendia que, a Constituição Federal estabeleceu que os tratados que versassem sobre os direitos humanos gozavam de hierarquia constitucional de acordo como artigo $5^{\circ}, \S 1^{\circ}$ e $\S 2^{\circ}$. O Supremo Tribunal Federal, em seus julgados manifesta o entendimento de que os tratados, que tratam dos direitos humanos, possuem o status de lei ordinária.

É importante também destacar que a emenda Constitucional no. $45 / 2004$, inovou no que concerne a incorporação dos tratados de direitos humanos no arcabouço jurídico brasileiro ao acrescer o $\S 3^{\circ}$ ao artigo $5^{\circ}$ da CF no qual consta que "os tratados e convenções internacionais sobre direitos humanos aprovados, em cada casa do Congresso Nacional, em dois turnos, por três quintos dos votos dos respectivos membros, serão equivalentes a emenda à Constituição".

No entanto, a inclusão deste mandamento não alberga os tratados anteriores à edição desta emenda que continuam gozando de posição de norma federal ordinária, por terem sido aprovados por maioria simples, e continuam a vigorar com status de lei ordinária. (WAMBIER, 2005)

Tal entendimento decorre do fato que os tratados que tratam de direitos humanos assinados e ratificados pelo Brasil sempre definiram a 
Artigo original

Hegemonia - Revista Eletrônica de Relações Internacionais do Centro Universitário Unieuro

ISSN: $1809-1261$

UNIEURO, Brasília, número 15, 2015, pp. 203-239.

tortura como crime próprio, mas a um nível de hierarquia supralegal, o que impediria a mudança trazida pela Lei n. 9.455/97, num patamar hierárquico inferior, de lei ordinária.

Como reforço a legalidade/constitucionalidade quanto à tipificação da tortura como crime comum é preciso considerar à própria norma internacional. A Convenção Contra a Tortura e Outros Tratamentos ou Penas Cruéis, Desumanos ou Degradantes trouxe em seu artigo $1^{\circ}, \S 2^{\circ} \circ$ seguinte mandamento: "O presente artigo não será interpretado de maneira a restringir qualquer instrumento internacional ou legislação nacional que contenha ou possa conter dispositivos de alcance mais amplo". Como é possível perceber este mandamento reporta ao $\S 1^{\circ}$ do mesmo artigo que definiu a tortura como crime próprio.

Desta forma, da própria norma internacional que classificou o delito de tortura como crime próprio, infere-se tal possibilidade ampliação que fora trazida pela Lei n. 9.455/97. Por força do mandamento legal existente, estando ou não inserida automaticamente em nosso ordenamento é possível perceber que a norma trouxe em seu bojo a autorização para essa classificação diversa, indo contra a afirmação feita pelos críticos que vislumbram o delito de tortura apenas como delito próprio.

Quando analisamos a questão da tortura no sistema penitenciário é preciso ter em mente que tanto na execução das penas alternativas como a das privativas de liberdade, faz-se necessário assegurar a dignidade humana principalmente no período de execução da pena onde o indivíduo já traz consigo a dignidade moral atingida pelo estigma da condenação. A Delcaração Universal dos Direitos do Homem, em seu art. $5^{\circ}$ diz que "ninguém será submetido a tratamento degradante." 
Artigo original

Hegemonia - Revista Eletrônica de Relações Internacionais do Centro Universitário Unieuro

ISSN: 1809-1261

UNIEURO, Brasília, número 15, 2015, pp. 203-239.

O Pacto de São José ou Convenção Americana sobre Direitos Humanos, também estabelece a proteção à integridade moral do condenado na aplicação e execução da pena, o respeito à dignidade inerente ao ser humano e à sua honra. A Constituição Federal de 1998 como não podia deixar de ser, também faz alusão ao assunto em seu art. $5^{\circ}$, inciso 111 declarando que ninguém será submetido a tratamento degradante.. E por fim, a Lei de Execuções penais fecha o assunto estabelecendo as normas para execução da pena, impondo a todas as autoridades que respeitem a integridade moral dos detentos, esclarecendo que a pena tem por objetivo proporcionar condições para a harmônica integração social dos detentos.

Na exposição de motivos da LEP, o projeto declara que torna-se inútil a luta contra os efeitos nocivos da prisionalização, sem que se estabeleça a garantia jurídica dos direitos do condenado e o Código Penal acrescenta em seu art. 38 que: "o preso conserva todos os direitos não atingidos pela perda da liberdade, impondo-se as autoridades o respeito à sua integridade fisica e moral".

Tendo em vista a necessidade dessas garantias jurídicas, o Ministério da Justiça estabeleceu as Regras Mínimas do Preso no Brasil, atribuindo no artigo 41 os seguintes direitos ao preso:

"Art. 41. Constituem direitos do preso:

I - alimentação suficiente e vestuário;

II - atribuição de trabalho e sua remuneração:

III- previdência social;

IV - constituição de pecúlio;

V - proporcionalidade na distribuição do tempo para o trabalho, VI- o descanso e a recreação;

VII - exercícios das atividades profissionais, intelectuais, artísticas e desportivas anteriores, desde que compatíveis com a execução da pena: assistência material, à saúde, jurídica. educacional. social e religiosa; VIII - proteção contra qualquer forma de sensacionalismo:

A respeito da execução de alguns desses incisos, podemos discorrer sobre alguns deles, para constatarmos o flagrante desrespeito à 
Artigo original

Hegemonia - Revista Eletrônica de Relações Internacionais do Centro Universitário Unieuro

ISSN: 1809-1261

UNIEURO, Brasília, número 15, 2015, pp. 203-239.

dignidade dos encarcerados. A alimentação suficiente em muitos estabelecimentos prisionais se resumem a um pedaço de pão no café da manhã. Para o almoço, arroz e feijão, macarrão e algumas vezes um pedaço de carne. Para o jantar come-se o que sobrou do almoço, segundo informações do Instituto de Pesquisa de Relações Internacionais (IPRI). Também é freqüente o consumo de alimentos estragados em virtude da falta de instalações adequadas para a produção de conservação das refeições. Muitas vezes a produção das refeições são terceirizadas, levando a esquemas de corrupção e superfaturamento, onde o preso que tem dinheiro paga para complementar sua marmita. Isso sem mencionar que em algumas regiões do país foram constatados casos em que os presos só recebiam alimentação uma vez por dia. (BITENCOURT, 1993)

Sobre o direito ao vestuário, a situação não é melhor. Anteriormente as prisões ofereciam uniformes que além de vestirem facilitavam o controle interno. Contudo, com as dificuldades financeiras enfrentadas pelo sistema essa prática deixou de ocorrer. Com isso, as necessidades de vestuário passaram a ser supridas geralmente pelas famílias, gerando quadro de desigualdades onde encontramos presos bem vestidos e agasalhados e presos que praticamente não tem com o que se cobrir, passando muitas vezes frio dentro das celas. (ZAFFARONI, 2011)

Com essas debilidades alimentares e de vestuários, entre outras questões de higiene, já podemos concluir pela deficiência da assistência quanto à saúde coletiva e individual. Em tais ambientes as epidemias são facilmente disseminadas, sendo resultantes das más condições sanitárias da habiltalidade ou da aglomeração de muitas pessoas em um pequeno espaço, como ocorre freqüentemente.

A tuberculose e as doenças sexualmente transmissíveis fazem parte da rotina médica dos presídios. Pesquisas indicam que o contingente carcerário trata-se de uma população com grande vulnerabilidade a 
Artigo original

Hegemonia - Revista Eletrônica de Relações Internacionais do Centro Universitário Unieuro

ISSN: 1809-1261

UNIEURO, Brasília, número 15, 2015, pp. 203-239.

doenças infecto-contagiosas, em específico a AIDS. Os testes que vem sendo aplicados indicam, em prisões com elevada concentração populacional tem demonstrado alta taxa de sorologia positiva. Para enfrentar esta situação, o sistema de saúde das prisões contam com as mais precárias instalações e condições de trabalho. (BITENCOURT, 1993)

Grande também é o desrespeito ao direito à assistência educacional e profissional. Muitos estabelecimentos contam com convênios com empresas que têm especialidades para a prestação do serviço educacional, uma vez que o serviço interno é ineficaz e desorganizado. Mesmo assim, os problemas enfrentados são muitos gerando um aprendizado deficiente e a decorrente evasão escolar, reflexo de uma população de baixa escolaridade. Com os insucessos da educação, a tentativa de profissionalização vai se tornando inútil. (ZAFFARONI, 2011)

O direito a prestação de serviços de assistência judiciária e social são do mesmo modo descumpridos. A maioria dos presos não tem recursos para constituírem advogados, ficando à mercê da assistência gratuita que conta com um baixo número de profissionais, criando problemas sérios como a morosidade dos processos, a falta de acompanhamento regular dos mesmos, entre outros infortúnios. Tal situação gera um péssimo efeito dentro dos estabelecimentos prisionais, a começar dos casos onde indivíduos ficam presos com a pena toda cumprida.

O serviço de assistência social se torna impotente frente a tantos problemas e deficiências encontrados no sistema, ficando sem ter como trabalhar a angústia e a ansiedade que fazem parte da condição dos apenados. A vida no cárcere leva o condenado a um processo de repressão dos seus desejos e uma autoanulação. Analisando o aprisionamento, alguns autores evidenciam que viver com "rituais e 
Artigo original

Hegemonia - Revista Eletrônica de Relações Internacionais do Centro Universitário Unieuro

ISSN: 1809-1261

UNIEURO, Brasília, número 15, 2015, pp. 203-239.

normas institucionais-sujeição a horários, a posturas, a normas violentas de convivência nas relações intersubjetivas - acentuam a incapacidade de lidar autonomamente com a própria vida, liberando, em contrapartida, desejos de dependência e de passividade, aliados a incontida agressividade, que tornam os tutelados pelas prisões seres inabilitados para a retomada de seus direitos civis em liberdade".

Neste processo, a assistência social e os mecanismos por ela utilizados não conseguem surtir efeitos sobre a personalidade dos presos, limitando-se apenas a serviços de ajuda de espécie filantrópica, como pequenas ofertas em dinheiro, auxílio por ocasião do reingresso na sociedade e auxílio para localizar parentes. A assistência social de resume a isso e mesmo que se pretenda fazer outro tipo de trabalho a insuficiência de recursos e o baixo número de funcionários qualificados impedem a realização de um trabalho de qualidade com efeitos mais eficazes. (ZAFFARONI, 2011)

Leis não faltam para que os direitos humanos dos detentos sejam respeitados, o que falta é fazer da letra da lei uma realidade a ser seguida por toda a sociedade, uma vez que há pessoas que pensam que preso não é gente e não merece um tratamento devido a todo ser humano Esses se calam frente ao massacre humano ocorrido todos os dias nas prisões, que mais parecem depósitos de gente, onde as pessoas são guardadas em celas coletivas, em condições mais do que sub-humanas. Talvez ignorem que nem mesmo a lei de proteção aos animais não toleram estes tipos de abusos. (BITENCOURT, 1993)

Muitos evocam os direitos das vítimas que foram atingidas sem sua integridade e dignidade, fazendo uma confusão de conceitos que não leva a lugar nenhum. Ora, as vítimas já foram justificadas a partir do momento em que a sociedade condena por meio do judiciário e inflige uma punição ao indivíduo pelo mal que praticou. Querer recusar a dignidade a essas 
Artigo original

Hegemonia - Revista Eletrônica de Relações Internacionais do Centro Universitário Unieuro

ISSN: 1809-1261

UNIEURO, Brasília, número 15, 2015, pp. 203-239.

pessoas é incorrer numa conduta tão errada quanto a delas quando da conduta do ato delitivo, devendo por isso a pessoa que recusa cumprir esses direitos serem também julgadas e da mesma forma condenadas.

Fato é que as agressões aos direitos humanos ocorrem todos os dias nas prisões, deflagrando juntamente com os fatores estudados no capítulo anterior a quantidade enorme de rebeliões que vemos em nosso país. Mais do que nunca, toda a sociedade precisa se empenhar para buscar soluções para tão delicada questão. É preciso considerar as perspectivas das penas alternativas e do respeito aos direitos humanos para o enfrentamento desumano encontrado em nosso sistema prisional. Portanto, não se pode ficar impassível ao tratamento degradante que ocorre em diversas prisoes brasileiras, mas buscar respostas mais eficazes à crise prisional e que sejam capazes de executar o processo de ressocialização tão necessário à ordem social.

Considerações Finais

A Constituição Federal foi cunhada tendo por fundamento a Declaração Universal dos Direitos do Homem de 1948, e em seus diversos artigos é possível perceber a inserção direitos humanos como consequência do processo de redemocratização do povo que vinha traumatizado por um regime militar.

Foi ampla a busca das garantias fundamentais do cidadão, tendo por base as normas instituídas na Declaração Universal dos Direitos do Homem, os direitos do homem devem ser protegidos de forma universal. Dentre as diversas garantias se tem à preocupação quanto à prática de tortura, o disposto no artigo $5^{\circ}$, que trata dos direitos e garantias fundamentais do cidadão. 
Artigo original

Hegemonia - Revista Eletrônica de Relações Internacionais do Centro Universitário Unieuro

ISSN: $1809-1261$

UNIEURO, Brasília, número 15, 2015, pp. 203-239.

Cabe destacar o inciso III, que estabelece: "ninguém será submetido à tortura nem a tratamento desumano ou degradante". Quanto ao tema discorrido outro dispositivo da Constituição Federal que merece destaque é o inciso XLIX que rege: "é assegurado aos presos o respeito à integridade física e moral". Artigo esse fruto do art. $5^{\circ}$ da Declaração Universal dos Direitos do Homem: "Ninguém será submetido à tortura, nem a tratamento ou castigo cruel, desumano ou degradante".

Diante dos citados dispositivos prevê-se que qualquer atividade que se enquadre nas hipóteses do já citado artigo $1^{\circ}$ da Convenção contra a Tortura e outros Tratamentos ou Penas Cruéis, Desumanos ou Degradantes, será tipificado como tortura no Brasil. Este era o objetivo do legislador quando criou a Constituição, não prevendo, porém que sua aplicabilidade restaria defeituosa e principalmente incompleta, já que inexistia uma lei autônoma que tipificasse a tortura.

Contudo, concluiu-se que, apesar da criação da Lei de Tortura, o que se viu no decorrer dos anos posteriores à sua edição, é que essa lei não é o que de fato inibe a prática. Se é que se pode dizer que esta é inibida. O que faz com que a tortura continue existindo é certo desconhecimento de tal lei, e também dos resultados que podem decorrer de uma prática de tortura. Além do mais, viu-se que, apesar de o agente ativo no crime de tortura poder ser qualquer pessoa, o maior índice de tortura atualmente é praticado pelas polícias, o que resulta na difícil apuração e no medo das vítimas em denunciá-las.

No século XXI, e principalmente nos países em desenvolvimento é possível cotidianamente verificar situações de tortura decorrente de uma cultura totalitária, apesar da existência de diversos acordos internacionais a respeito do tema, em que o Brasil é signatário. 
Artigo original

Hegemonia - Revista Eletrônica de Relações Internacionais do Centro Universitário Unieuro

ISSN: $1809-1261$

UNIEURO, Brasília, número 15, 2015, pp. 203-239.

A importância do problema é tal que o combate à prática de tortura esta albergada no artigo 5, III da Constituição Federal de 1988. A prática de tortura ganhou sua tipificação como crime por meio da Lei n. Lei 9.455/97, dando ao delito a classificação de crime comum, e que foi razão de controvérsias e questionamentos.

A tortura é um mal que ataca a integridade física e psicológica da pessoa humana, e fere um dos principais bens jurídicos: a vida. Assim, percebemos que a tentativa do legislador em dar maior alcance a norma, deve ser vista como positiva, objetivando uma maior proteção às vítimas da tortura.

A Lei n. 9.455/97 alargou os limites de aplicação constantes nos tratados e convenções assinados pelo Brasil. Como vimos, ela agiu amparada pela total legalidade constante no entendimento do Supremo Tribunal Federal, que equiparou esses tratados e convenções internacionais a normas infraconstitucionais e nos próprios acordos internacionais, que autorizaram tal tipificação.

Notamos uma grande ineficácia quanto à aplicação da lei de tortura, pois são poucos os casos de apuração, de processos instaurados ou de condenação. Mesmo assim, diante da tipificação da tortura dada pelo ordenamento jurídico pátrio, podemos presenciar alguns poucos casos em que constatamos a aplicação da norma.

Seria totalmente inconveniente para a sociedade brasileira que pessoas que cometessem atos de extrema violência e crueldade pudessem ser retiradas do alcance da lei por não possuírem algum tipo de característica ou qualidade, ou seja, de não serem funcionários do Estado ou estarem a este ligado de alguma forma.

Importante agora é que o sistema, por meio de suas instituições, possa propiciar meios para que a lei em tela tenha uma maior efetividade 
Artigo original

Hegemonia - Revista Eletrônica de Relações Internacionais do Centro Universitário Unieuro

ISSN: 1809-1261

UNIEURO, Brasília, número 15, 2015, pp. 203-239.

na sua aplicação, entre os particulares ou servidores estatais, consubstanciado na busca pela manutenção do Estado Democrático de Direito que é gravemente arranhado pela existência de prática tão odiosa.

Contudo, mesmo com esta nova roupagem, a pena não se modificou em sua estrutura arquetipica, permanecendo, pois o sentimento de vingança que dificulta a execução racional da pena, uma vez que tal sentimento leva a sociedade a castigar o delinqüente por duas vezes. Uma com o devido processo legal, onde é condenado e recebe a pena pela qual paga por seus crimes e outra quando é submetido a essa execução, sendo ali abandonado a uma condição de inimigo da sociedade e nocivo ao convívio social, fator este que já começa a indicar as razões pelas quais a ressocialização inexiste no sistema carcerário.

Além deste, muitos outros fatores foram apresentados como condicionantes da ineficácia das prisões na ação recuperacional. A superlotação das cadeias, as condições rudimentares de higiene e estruturas sanitárias, a alimentação de péssima qualidade, a falta de assistência médica, jurídica e educacional, a ociosidade a que são submetidos e a promiscuidade proveniente dela, a violência no trato entre os presos e entre esses e os agentes penitenciários, a falta de formação profissional dos mesmos, a estrutura interna do sistema que anula o indivíduo fazendo com que se preocupe apenas com sua sobrevivência, fechando, deste modo, os caminhos para o aprendizado de uma vida em liberdade, bem como os outros fatores que não foram expostos por envolverem questões complexas pertinentes à psicologia. Porém., os argumentos levantados foram suficientes para concluirmos pela total ineficácia dos atuais sistemas prisionais na recuperação dos presos e sua saudável reinserção na rotina social. 
Artigo original

Hegemonia - Revista Eletrônica de Relações Internacionais do Centro Universitário Unieuro

ISSN: 1809-1261

UNIEURO, Brasília, número 15, 2015, pp. 203-239.

Referências bibliográficas

ARNS, Paulo Evaristo. Brasil Nunca Mais. 11 ed. Petrópolis: Vozes, 1985.

BECCARIA, Cesare. Dos Delitos e Das Penas. São Paulo: Martin Claret, 2000.

BIAZEVIC. Daniza Maria Haye. A História da Tortura. Disponível em: <http://jus.uol.com.br/index.html>. Acesso em 10 de set. de 2011.

BITENCOURT, Cézar Roberto. Falência da pena de prisão. 3. ed. Revista dos Tribunais. São Paulo, 1993.

BORGES, José Ribeiro. Tortura: Aspectos Históricos e Jurídicos: O crime de tortura na legislação brasileira - análise da lei 9.455/97. Campinas: Romana, 2004.

BORGES, José Ribeiro. Tortura: Aspectos Históricos e Jurídicos: O crime de tortura na legislação brasileira - análise da lei 9.455/97. Campinas: Romana, 2004, p.130.

BORGES. José Ribeiro. Tortura. Campinas: Romana, 2004.

BOUCAULT, Carlos Eduardo de Abreu; Araújo Nádia (Org.). Os Direitos Humanos e o Direito Internacional. Rio de Janeiro: Renovar, 1999.

CAMELLO TEIXEIRA, Flávia. Da Tortura. Belo Horizonte: Del Rey, 2004.

CAPEZ, Fernando. Curso de Direito Penal, Legislação Penal Especial, vol. 4. São Paulo: Saraiva, 2006, pp. 657-658.

COIMBRA, Mário. Tratamento do Injusto Penal da Tortura. São Paulo: RT, 2002

COMPARATO, Fábio Konder. A Afirmação Histórica Dos Direitos Humanos. 2 ed. São Paulo: Saraiva, 2001.

FRANCO, Alberto Silva. Breves Anotações Sobre A Lei 9455/97. Revista Brasileira de Ciências Criminais, V. 05, n. 19, jul/set. 1997, p. 60.

HERKENHOFF, João Baptista. Historia dos Direitos Humanos no Brasil. Disponível em:<http://www.dhnet.org.br/direitos/militantes/herkenhoff/livro1/dhbr asil/br1.html.> Acesso em: 18 de set. de 2012 
Artigo original

Hegemonia - Revista Eletrônica de Relações Internacionais do Centro Universitário Unieuro

ISSN: 1809-1261

UNIEURO, Brasília, número 15, 2015, pp. 203-239.

JUNIOR, Rolf Koerner. Código Criminal de 1830. Disponível em: <http://www.dantaspimentel.adv.br/jcdp5217.htm>.Acesso em 18 de set. de 2012.

JURICIC, Paulo. Crime de Tortura. São Paulo: Juarez de Oliveira, 1999.

LIMA, Marcellus Polastri. Comentário à Lei de Tortura: aspectos penais e processuais penais. Riode Janeiro: Lumen Juris, 2006.

MARZAL, Alezandro Del Toro. La Reforma del Derecho Penal. Barcelona: Universidad Autônoma de Barcelona, 1980, p. 271. Apud, FRANCO, Alberto Silva. Breves Anotações Sobre A Lei 9455/97. Revista Brasileira de Ciências Criminais, V. 05, n. 19, jul/set. 1997, p. 60.

MELLO, Cleyson de Moraes; FRAGA, Thelma Araújo Esteves. Direitos Humanos: coletânea e Legislação: Rio de Janerio: F. Bastos, 2003.

NUCCI, Guilherme de Souza. Leis Penais e Processuais Penais Comentadas. 1 ed. São Paulo: Revista dos Tribunais, 2006.

PIERANGELI. José Henrique. Códigos Penais do Brasil. 2 ed. São Paulo, Editora Revista dos Tribunais, 2001.

PIOVESAN, Flávia. Direito Humanos e o Direito Constitucional Internacional.5.ed. São Paulo: Max Limonand, 2002.

PONTIERI, Alexandre. Breves Considerações Sobre a Tortura. Revista Jurídica. São Paulo, V. 52, n. 324, out. 2004.

QUEIROZ, Carlos Alberto Marchi de. Resumo de Direitos Humanos e da Cidadania. São Paulo, Iglu, 2001.

SHECAIRA, Sérgio Salomão. Algumas Notas Sobre A lei de Tortura. Boletim IBCCRIM n. 54, maio de 1997, p. 02.

SILVA, José Geraldo; LAVORENTI, Wilson; GENOFRE, Fabiano. Leis penais especiais anotadas. Campinas: Millenium, 2004, p. 144

STOCO, Rui. A Tortura Como Figura Típica Autônoma. Enfoque Jurídico do TRF, da $1^{\text {a }}$ Região, Março-Abril. 1997, p. 4.

TEIXEIRA, Flávia Camello. Da Tortura. Belo Horizonte: Del Rey, 2004.

TRINDADE, Augusto Cançado. A proteção Internacional dos Direitos Humanos e o Brasil. 2.ed. Brasília: Fundação Universidade de Brasília, 2000. 
Artigo original

Hegemonia - Revista Eletrônica de Relações Internacionais do Centro Universitário Unieuro

ISSN: $1809-1261$

UNIEURO, Brasília, número 15, 2015, pp. 203-239.

WAMBIER, Teresa Arruda Alvim. Et. Al. Reforma do judiciário: primeiros ensaios críticos sobre a EC N. 45/2004. São Paulo: Editora dos tribunais, 2005.

ZAFFARONI, Eugênio Raúl. Em Busca das penas perdidas: a perda de legitimidade do sistema penal. Tradução Vânia Romano Pedrosa e Amir Lopez Conceição. 5 ed. Rio de Janeiro, Ed.Revan, 2001. 